\title{
Spor Bilimleri Fakültesi Öğrencilerinin Öğretmen Öz-yeterlik İnançları ve Öğretim Tekniklerini Seçebilme Yeterlikleri
}

\author{
Aynur YILMAZ ${ }^{1}$, Emrah ASLAN ${ }^{2}$ ve Sinan AYAN $^{3}$ \\ Öz
}

Bu çalışmanın amacı beden eğitimi öğretmen adaylarının öz-yeterlik inancı ve öğretim tekniklerini seçebilme yeterlik algılarını tespit etmektir. Araştırma nicel araştırma yaklaşımından ilişkisel tarama modeli ile tasarlanmıştır. Araştırma, 2017-2018 eğitim-öğretim yılı bahar yarıyılında, Kırıkkale Üniversitesi Spor Bilimleri Fakültesi 3. ve 4. sınıf öğrencileri üzerinde gerçekleştirilmiştir. Bu öğrenciler fakültedeki farklı bölümden (Beden Eğitimi ve Spor Öğretmenliği=66, Antrenörlük Eğitimi=38, Spor Yöneticiliği=79 ve Rekreasyon=44) öğrenciler olmak üzere toplam 227 öğretmen adayından oluşmaktadır. Veriler araştırmacılar tarafından hazırlanan "Kişisel Bilgi Formu", Çapa, Çakıroğlu ve Sarıkaya (2005) tarafından Türkçeye uyarlaması yapılan "Öğretmen Öz-yeterlik Ölç̧eğì ve Fırat Durdukaya vd. (2017) tarafından geçerlik ve güvenirlik çalışması yapılan "Öğretmen Adaylarının Öğretim Tekniklerini Seçebilme Yeterliği Ölçeği” aracilığıyla elde edilmiştir. Veri analizinde; betimsel istatistikler (aritmetik ortalama, standart sapma), bağımsız gruplar t-testi, tek yönlü varyans analizi, basit doğrusal regresyon analizi ve Pearson Correlation testi kullanılmıştır. Sonuç olarak öğretmen öz-yeterlik inancı öğretim tekniklerini seçebilme yeterliğini anlamlı şekilde yordamaktadır. Öğretim tekniklerini seçebilme yeterlik algısı ve öğretmen öz-yeterlik inanc1 puan ortalamaları öğretmen adaylarının okudukları bölüme göre farklılık gösterirken; cinsiyet ve mezun olunan okul türüne göre anlamlı farklılık göstermediği belirlenmiştir. Bu bulgular ışığında; öğretmen öz-yeterlik inancı öğretim tekniklerini seçebilme yeterliği açısından önemli olduğu söylenebilir.

Anahtar Kelimeler: Öğretmen Öz-yeterlik İnanc1, Öğretim Teknikleri, Spor Bilimleri Fakültesi Öğrencileri

\section{Teachers' Self-Efficacy Beliefs of Sport Science Faculty Students and Competence to Choose Teaching Techniques}

\section{Abstract}

The aim of this study is to determine the self-efficacy beliefs of physical education teacher candidates and their perception of competence to choose teaching techniques. The research was designed with a relational search model, which is one of the quantitative research approaches. The research was conducted on the third and fourth year students of the Faculty of Sports Sciences of Kirikkale University in the spring semester of 2017-2018 academic years. These students consist of a total of 227 teacher candidates (Physical education and sports teaching= 66, Coaching training $=38$, Sport management $=79$ and Recreation $=44)$ from the different departments in the faculty. Data were obtained by means of "Teacher Self-efficacy Scale" adapted by Çap1, Çakıroğlu and Sarıkaya (2005) and Firat Durdukaya et al. (2017). The validity and reliability study was conducted by means of the "Teacher Candidate's Teaching Techniques Succeeding Sufficiency Scale" and "Personal Information Form" prepared by the researchers. In data analysis, descriptive statistics (arithmetic mean, standard deviation), independent groups t-test, one way variance analysis, simple linear regression analysis and Pearson Correlation test were used. As a result, teacher selfefficacy belief significantly predicts the adequacy of choosing teaching techniques. In addition, the ability to choose teaching techniques and the teacher self-efficacy belief score averages differ according to the grades read by the teacher candidates. Besides, it did not show any significant difference according to sex and graduated school type. In the light of these findings, it can be said that teacher is important in terms of the ability to choose teaching techniques of self-efficacy beliefs.

Key Words: Teacher Self-efficacy Belief, Teaching Techniques, Faculty of Sport Sciences Students

\section{Atıf İçin / Please Cite As:}

Yılmaz, A., Aslan, E. ve Ayan, S. (2020). Spor bilimleri fakültesi öğrencilerinin öğretmen öz-yeterlik inançları ve öğretim tekniklerini seçebilme yeterlikleri. Manas Sosyal Araştırmalar Dergisi, 9(1), 435-448.

Geliş Tarihi / Received Date: 26.12.2018

Kabul Tarihi / Accepted Date: 06.06.2019

\footnotetext{
${ }^{1}$ Dr. Öğr. Üyesi - Trabzon Üniversitesi Spor Bilimleri Fakültesi, aynuryilmaz@trabzon.edu.tr - ORCID: 0000-0001-7562-9469

2 Arş. Gör. Dr. - Kırıkkale Üniversitesi Spor Bilimleri Fakültesi, emrahaslan@kku.edu.tr - ORCID: 0000-0002-0284-8350

${ }_{3}^{3}$ Doç. Dr. - Kırrkkale Üniversitesi Spor Bilimleri Fakültesi, sayan@kku.edu.tr - ORCID: 0000-0001-5691-8302
} 


\section{Giriş}

Öğretim teknikleri, öğretmen adayları için temel bilgi ve beceri düzeylerini artırma ve etkin kullanmada önemli bir enstrüman olarak ortaya çıkmaktadır. Öğretmen adaylarının bu başlıktaki özyeterlik inancı doğaldır ki öğretim hedeflerini belirlemesi, öğretim ilkelerini doğru değerlendirebilmesi ve öğretim içeriğini oluşturması üzerinde etkili olacaktır.

Öz-yeterlik Bandura'ya göre, bireyin davranışlarının oluşmasında etkili olan ve belirli performansı sergileyebilmek için gerekli faaliyetleri planlayıp, bu faaliyetleri başarılı bir şekilde gerçekleştirebilmek için kendine olan inancıdır (Bandura, 1997). Başka bir tanıma göre öz-yeterlik; kişinin istediği davranışı yapabilmesi için gerekli olan yeteneğine dair özgüveni, kendine verilen görevdeki devamllık derecesi ve gösterdiği çabadır (Kinzie, Delcourt ve Powers, 1994, s. 747).

Öz-yeterlik kavramı hemen hemen her alanda kişinin başarı elde etmesinde, yetki ve sorumluluğunu en iyi şekilde kullanabilmesinde önemli görülmekte, mesleki olarak yetkinliği en iyi biçimde ortaya koyabilmesinde önemlidir. Pedagojik bilgi ve beceri yetkinliği, konu alanı hâkimiyeti, sınıf yönetimi, uygun öğretim yöntem ve tekniklerini seçebilme ve kullanabilme, etkili iletişim vb. yetki ve sorumluluğuna sahip olan öğretmenlik mesleği için öz-yeterlik önemli bir kavramdır. Bu kavram; öğretmen açısından değerlendirildiğinde, öğretmenliğin gerektirdiği görev ve sorumluluklar1 yerine getirebilmek için sahip olunması gereken bilgi, beceri ve tutumları açıklamaktadır. Öğretmenlik mesleğine yönelik öz-yeterlik kavramını, Tschannen-Moran ve Hoy (2001, s. 783) "bir öğretmenin öğrencilerinin arzu edilen öğrenme sonuçlarını oluşturma kapasitesine veya yeteneğine ilişkin inancı" olarak tanımlarken; Ashton (1984) "öğrencilerin performanslarını etkileme kapasitelerine olan inançları" olarak tanımlanmıştır. Guskey ve Passaro (1994) ise "öğretmenlerin, öğrencilerine etkili bir eğitim-öğretim verme konusunda kendilerine güven duymalarına ilişkin inançları" olarak öğretmen öz-yeterlik kavramını açıklamıştır.

Öğretmen öz-yeterliği, öğretmen eğitiminde önemli bir yapıdır ve öğretmen öz-yeterliğinin nasıl geliştiği, hangi bileşenlerden oluştuğu, güçlü ve pozitif öğretmen yeterliğine hangi faktörlerin katk1 sağladığ1, yüksek düzey bir öğretmen yeterliği geliştirmeye yönelik hangi eğitim programlarının nasıl geliştirileceğinin belirlenmesi için oldukça önemlidir (Pajares, 1997). Öğretmenlerin yüksek öz-yeterlilik algısına sahip olmaları, öğrencilerin akademik başarılarının artmasına, derse olan tutumlarının olumlu yönde değişmesine ve böylece öğrencilerin davranışlarının sınıf yönetimi açısından öğretmene kolaylık sağlayacaktır. Bu durum, öğrencilere olumlu bir sınıf atmosferinde dersin kazanımlarını elde etme firsatı sunacaktır. Öğretmen adaylarının öz-yeterlik inançlarını ele alan çalışmalar göstermektedir ki, yüksek özyeterlik inanc1 öğretmenin öğrenme-öğretme sürecindeki sebatını, performansını, eğitim-öğretim sürecini planlama ve uygulamasını (Milner ve Woolfolk-Hoy, 2002), öğretmenin duygusal durumunu ve sınıf yönetimini etkilemektedir (Denzine, Cooney ve McKenzie, 2005, s. 705; Pendergast, Garvis ve Keogh, 2011, s. 46). Buradan hareketler yüksek özgüvene sahip olan öğretmen adaylarının, ders esnasında çeşitli öğretim yöntem ve tekniklerini etkili şekilde kullanabilmelerinde sahip oldukları öz-yeterlik inancinın önemli rol oynadığı söylenebilir.

Öğretim programlarında belirtilen hedeflere ulaşmanın en kolay yollarından biri uygun zamanda seçilmiş doğru öğretim yöntem ve teknikleri kullanmaktır. Öğretim yöntemi öğrenci özellikleri, ders araç gereçlerinin uygunluğu ile tüm öğrenme durumu göz önünde bulundurularak belirlenen ve izlenen yol olarak tanımlanmaktadır. Kısaca hedefe ulaşmak için izlenen en kısa yoldur (Demirel, 2003, s. 25). Dersin uygulanmasında belirlenen öğretme yöntemini uygulamaya koyma biçimi ise öğretim tekniği olarak nitelendirilmektedir. Öğretmenin yapması gereken, hedeflerin belirlenmesi ve gerçekleştirici nitelikte öğrenme yaşantılarının seçimini, öğretimin etkili olabilmesinde öğretim tekniklerinin rolü ve iç görülerini dikkate almaktır (Bilen, 2002).

Öğretim teknikleri yaygın olarak geleneksel ve çağdaş öğretim teknikleri olarak ikiye ayrılmaktadır. Geleneksel öğretim; dersin daha çok öğretmen merkezli işlendiği, öğretmenin bilgilendirici rolünde olup, öğrencinin dinleyici konumunda olduğu bir yaklaşımdır. Öğrenci bilgiyi olduğu gibi aldıği için, bilgiyi işleyemez, anlamlandıramaz, anlamlandırılmayan bilgi de kısa sürede unutulur ve kaybolur. Merkeze ögretmeni alan bu yaklaşımda genellikle anlatım, soru-cevap ve gösteri tekniğinden faydalanılır. Öğrencinin aktif olarak rol almasına firsat vermeyen yaklaşım; sınıf yönetimi, ögretim yöntem ve tekniklerini kullanım açısından yeterli öz-yeterliğe sahip olmayan öğretmenlerin sınıf hâkimiyeti kaybetme korkusu ya da dersi farklı yaklaşımlarla uygulama bilgi ve becerisine sahip olmayanların tercih ettiği bir yaklaşım olarak tanımlanabilir. Wheatley (2005, s. 17), öz-yeterlik inancı yüksek olan öğretmenlerin düşük olan öğretmenlere göre çağdaş ögretim etkinliklerini sınıf içerisine dâhil etmeye daha yatkın olduklarını ileri 
sürmüştür. Önen, Saka, Erdem, Uzal ve Gürdal (2008, s. 140) yaptıkları çalışmada, farklı branşlardaki ögretmenlerin derslerinde öğretim yöntem-teknik ve stratejilere ilişkin yeterli bilgi ve beceriye sahip olmadıklarından, genellikle öğretmeni merkeze alan yöntem-teknik ve stratejileri tercih ettikleri gözlemlenmiştir. Etkin bir eğitim ve öğretimin yapilabilmesi için, öğretmen eğitimi programları teoriye dayalı öğretmen merkezli yaklaşımdan daha çok uygulamaya dayalı öğrenci merkezli yaklaşıma doğru kaymas1 gerekmektedir (Oddens, 2004, s. 350). Öğretim tekniklerinde bir diğer yaklaşım ise bilginin öğrenci tarafindan yapılandırılması, anlamlandırılması, karşılaşılan yeni durumlar karşısında çözüm önerilerinin geliştirilmesi, bilginin içselleştirilmesine firsat sunan çağdaş öğrenme yaklaşımdır. $\mathrm{Bu}$ yaklaşımda öğretmen bilgi aktaran rolünde değil, öğrencilerine bilgiye nerede ve nasıl ulaşacağını gösteren bir yol gösterici rolündedir. Öğrenci ise daha aktif, araştıran, sorgulayan ve belirli farkındalıkları olan birey rolündedir. Bu yaklaşımda öğretmene önemli sorumluluklar düşmektedir (Uzunboylu ve Hürsen, 2011, s. 454-455).

Öğrencilerin gerekli becerileri kazanabilmeleri, öğretmenlerin öğretim sürecinde etkin yöntemleri ve uygun materyalleri kullanarak öğretim yapmalarına bağlıdır. Öğretmenler öğrencilerine, mevcut bilgileri ezberletmek yerine, kavramalarını sağlamalı, karşılaşılan yeni durumlar karşısında problem çözme becerilerini geliştirmeli, bilimsel yöntem ve süreçleri kullanmayı öğretmelidirler. Erden'e göre (2007) öğretim yöntem ve tekniklerinin etkililiği üzerinde yapılan araştırmalar bütün öğrenmeler için gerekli tek bir öğretim yönteminin olmadığını göstermektedir. Özellikle uygulamalı bir alana sahip olan beden eğitiminde, öğretim yönteminin seçiminde sınıf mevcudu, malzeme ve tesislerin varllğı yöntemin belirlenmesinde önemli kriterler olarak kabul edilse de; öğrencinin yaş ve yetenek seviyesi de öğretim yöntem ve tekniklerin seçiminde büyük öneme sahiptir (Tamer ve Pulur, 2001, s. 28). Özellikle ders esnasında öğretmenin farklı yöntem, teknik ve öğrenme yollarından yararlanması öğretimin bireyselleştirilmesine katk1 sağlayacaktır. Öğrenmede bireysel farkllıkların var olduğu dikkate alındığında; farklı öğretim yöntem ve teknikleri öğrencinin tam öğrenmeyi gerçekleştirmesini kolaylaştıracaktır.

Beden eğitiminde yaygın olarak sunuş ve buluş yaklaşımları kullanılmaktadır (Mosston ve Ashworth, 2008, s. 53). Sunuş yolu ile öğrenme geleneksel yöntemde olduğu gibi daha çok öğretmen merkezli yaklaşımın özelliklerini göstermektedir. Bu yaklaşımda komut, alıştırma, eşli çalışma, kendini denetleme ve katılım stili olmak üzere öğretmenin öncülügünde gerçekleştirilen teknikler kullanılmaktadır. Bir diğer yaklaşım ise çağdaş öğrenme yaklaşım özellikleri ile benzerlik göstermekte olup, öğrenciyi merkeze alan öğrencinin yaparak yaşayarak öğrenmesine firsat sunan buluş yöntemidir. Bu yaklaşım yönlendirilmiş buluş, problem çözme, öğrencinin başlatması, kendi kendine öğretme tekniklerini içermektedir.

Öğretmenin derste birden fazla duyu organına hitap eden öğretim yöntem ve tekniğini kullanması, öğrencilerin derse olan dikkatlerinin dağılmasını önleyebilir, öğretimi bireyselleştirebilir ve böylece öğrenmeyi kalıcı hale getirebilir. Öğretmenlerin yöntem konusunda seçici olabilmeleri, onların sahip oldukları yöntem zenginliği ile yakından ilişkili olduğu söylenebilir. Klein, Matkins ve Waver (1999) yapmış oldukları çalışmada öğretmenler arasında en yaygın olarak kullanılan öğretim yöntemleri arasında, sıkıcı ve etkisiz yöntem olarak nitelendirilen düz anlatım ve soru-cevap yöntemleri kullanıldığ1 tespit edilmiştir. Beden eğitimi derslerinde ise anlatım, gösterip yaptırma ve alıstırma tekniklerine yer verildiği söylenebilir.

Yüksek öz-yeterlik inancının kazanılmasında, hizmet öncesi eğitim-öğretimde öğretmen adaylarının kazandıkları bilgi ve becerilerin önemi büyüktür. Bozpolat, Uğurlu, Usta ve Şimşek'in (2016, s. 91) öğretmen adayları üzerinde gerçekleştirdiği çalışmada, öğretmen adaylarının öğretim tekniklerinin seçimi ve kullanımı konusundaki yetersiz bilgiye sahip oldukları tespit edilmiştir. Yılmaz ve Namlı'nın (2017, s. 3070) öğretmenlik uygulamasına katılan öğretmen adaylarının mesleki yeterliklerini belirlemek amacıyla yaptıkları çalışmada; öğretmen adaylarının konu eksikliği olduğu, öğretimi çeşitlendiremedikleri, farklı yaklaşımlar kullanamadıkları saptanmıştır. Ertan ve Çiçek’in (2003, s. 81) çalısmasında öğretmenlerin daha çok sunuş yoluyla öğrenme yaklaşımının içerdiği komut ve alıştırma yöntemlerini kullandıkları görülmüştür.

Beden eğitimi derslerinde kullanılan yöntemlerin çeşitlendirilemediği; anlatım, gösterip yaptırma gibi kısmen öğretmen kısmen öğrencinin merkezde yer aldığı tekniklerin tercih edildiği literatürde görülmektedir. Beden eğitimi öğretmen adaylarının sahip oldukları öz-yeterlik algısı ve öğretim tekniklerini seçebilme yeterliği arasında ilişki olabileceği, bu değişkenlerin birbirini etkileyen unsurlar olduğu öngörülmektedir. $\mathrm{Bu}$ amaçla konuya ilişkin yapılan literatür taraması yapılmışır. Ancak, beden eğitimi ögretmen adaylarının öz-yeterlik inançları ve öğretim tekniklerini kullanma yeterliğinin birlikte incelendiği çalışmanın mevcut olmadığı tespit edilmiştir. Bu çalışmada; beden eğitimi öğretmen adaylarının öz-yeterlik 
inanc1 ve öğretim tekniklerini seçebilme yeterlik algılarını farklı değişkenler açısından incelemek amaçlanmıştır. Bu amaç doğrultusunda aşağıdaki alt problemler cevaplandırılmıştır.

1. Öğretmen adaylarının öz-yeterlik inançları ile öğretim tekniklerini seçebilme yeterlik algıları puan ortalamaları hangi düzeydedir?

2. Öğretmen adaylarının öz-yeterlik inançları ile öğretim tekniklerini seçebilme yeterlik algıları arasında anlamlı bir ilişki var mıdır?

3. Katılımcıların öğretmen öz-yeterlik inançları, öğretim tekniklerini seçme yeterlik algılarının anlamlı bir yordayıcisı midir?

4. Katılımcıların öz-yeterlik inançları ve öğretim tekniklerini seçebilme yeterlik algısı puan ortalamaları, cinsiyete göre anlamlı bir farklılık göstermekte midir?

5. Katılımcıların öz-yeterlik inançları ve öğretim tekniklerini seçebilme yeterlik alg1sı puan ortalamaları ile akademik not ortalamaları arasında anlamlı ilişki var mıdır?

6. Katılımcıların öz-yeterlik inançları ve öğretim tekniklerini seçebilme yeterlik algısı puan ortalamaları, okudukları bölüme göre anlamlı bir farklılık göstermekte midir?

7. Katılımcıların öz-yeterlik inançları ve öğretim tekniklerini seçebilme yeterlik algısı puan ortalamaları, mezun oldukları lise türüne göre anlamlı bir farklılık göstermekte midir?

\section{Yöntem}

Araştırmanın bu bölümünde araştırmanın deseni, çalışma grubu, verilerin toplanması ve verilerin analizi başlıklarına yer verilmiştir.

\section{Araştırma Deseni}

Araştırmada geniş gruplar üzerinde yürütülen, gruptaki bireylerin bir olgu veya olayla ilgili görüşlerinin, tutumlarının alındığı, olgu ve olayların kendi koşulları içinde ve olduğu gibi betimlenmeye çalışıldığı tarama yöntemi (Karasar, 2005) kullanılmıştır.

\section{Çalışma Grubu}

Çalışma, 2017-2018 Eğitim-Öğretim y1lı bahar yarıylında, Kırıkkale Üniversite’si Spor Bilimleri Fakültesi 3. ve 4. sınıf öğrencileri üzerinde gerçekleştirilmiştir. Çalışma, fakültedeki farklı bölümden (Öğretmenlik n=66, Antrenörlük=38, Yöneticilik=79 ve Rekreasyon=44) olmak üzere toplam 227 öğretmen adayı üzerinde gerçekleştirilmiştir. Çalışma grubu seçiminde, amaçlı örnekleme yöntemlerinden ölçüt örnekleme ile kullanılmıştır. Katılımcıların "Öğretim yöntem ve teknikleri” dersini almaları ölçüt olarak belirlenmiştir. Farklı bölümlerdeki öğrencilerin formasyon almış ya da alıyor olmalarına dikkat edilmiştir.

\section{Veri Toplama Araçları}

Araştırmada veri toplama araçları olarak, "Kişisel Bilgi Formu”, “ Öğretmen öz-yeterlik İnançları ölçeği” ve "Öğretmen adayları öğretim tekniklerini seçebilme yeterlikleri algısı ölçeği” kullanılmıştır.

Kişisel Bilgi Formu: Araştırmaya konu olan öğretmen adaylarının öğretmen yeterlik inançları hakkında bilgi toplamak amacıyla araştırmacılar tarafindan oluşturulan 'Kişisel Bilgi Formu hazırlanmıştır. Bu form, katılımcıların cinsiyet, not ortalaması, okudukları bölüm, mezun oldukları lise türü gibi bağımsız değişkenleri içermektedir.

Ögretmenlik Öz-yeterlik. Ölçeği: Çapa, Çakıroğlu \& Sarıaya (2005) tarafindan Türkçe’ye uyarlaması yapılan "Öğretmen Öz-yeterlik Ölçeği”, öğrenci sorumluluk yeterliliği, öğretim stratejileri yeterliliği ve sinıf yönetimi yeterliği olmak üzere üç alt faktör ve 24 maddeden oluşmaktadır. Ölçme arac1 9'lu Likert tipi olup, ölçekten alınabilecek en düşük puan 24 iken, en yüksek puan 216'dır. Ölçeğin geneli ve alt boyutlarının güvenirliğine ilişkin Cronbach Alpha iç tutarlık katsayısı hesaplanmıştır. Ölçeğin geneli için bu değer 0.95 iken; alt boyutları için bu değer 0.85 ile 0.88 arasında değişmektedir. Mevcut çalışma kapsamında da ölçeğin yapı geçerliği ve güvenirliği sınanmıştır. Bu araştırma kapsamında toplanan veriler üzerinde hesaplanan Cronbach alfa iç tutarlık katsayısı ise 0.92 olarak bulunmuştur. Ölçeğin alt boyutlarına ilişkin güvenirlik değerleri "Öğrenci sorumluluk yeterliği” için 0.93 , "Öğretim stratejileri yeterliği” için 0.88 ve "Sınıf yönetimi yeterliğ̣" için 0.85 olarak hesaplanmıştır. Ölçeğin yap1 geçerliğine kanıt sağlamak amacıyla yapılan Doğrulayıcı Faktör Analizi sonucunda elde edilen uyum indeksleri $\chi^{2} / \mathrm{df}=1.26$, RMSEA $=0.062, \mathrm{GFI}=0.87, \quad \mathrm{AGFI}=0.88, \mathrm{CFI}=0.94, \mathrm{NFI}=0.95, \mathrm{IFI}=0.95, \mathrm{PNFI}=0.83$ olarak hesaplanmıştır. Bu değerler ölçeğin üç faktörlü yapısının mevcut çalışma grubunda da doğrulandığını 
göstermektedir. Yirmi dört maddeden oluşan üç faktörlü yapının madde faktör yük değerleri 0.67 ile 085 arasında değerler alırken, maddelere ilişkin t değerleri ise 14.48 ile 19.10 arasında değişmektedir.

Öğretmen Adaylar Öğretim Tekniklerini Seçebilme Yeterliüi Ölçĕğ: Firat Durdukaya vd. (2017) tarafindan geliştirilen ölçme arac1 "Teknik seçimine ilişkin olumlu öngörü" ve "Teknik seçimine ilişkin olumsuz öngörü” olmak üzere iki faktör ve 22 maddeden oluşmaktadır. Ölçme aracı 5'li likert tipinde olup, ölçekten alınabilecek en düşük puan ve yüksek puan sırasıyla 22 ve 110 'dur. Güvenirliğe ilişkin hesaplanan Cronbach Alpha değeri ölçeğin geneli için 0.90 'dır. Alt boyutları için sırasıyla 0.92 ve $0.88^{\prime}$ dir. Mevcut çalışma kapsamında ölçme aracının geçerlik ve güvenirlik değerleri hesaplanmıştır. Cronbach alfa iç tutarlık katsayısı ölçeğin geneli için 0.86 olarak bulunmuştur. Ölçeğin alt boyutlarına ilişkin güvenirlik değerleri ise "Teknik seçimine ilişkin olumlu öngörü" için 0.70 ve "Teknik seçimine ilişkin olumsuz öngörü" için 0.82 'dir. Ölçeğin yapı geçerliğine kanıt sağlamak amacıyla yapılan Doğrulayıcı Faktör Analizi sonucunda elde edilen uyum indeksleri $\chi 2 / \mathrm{df}=1.34$, RMSEA $=0.057, \mathrm{GFI}=0.89, \mathrm{AGFI}=0.87, \mathrm{CFI}=0.96, \mathrm{NFI}=0.95$, $\mathrm{IFI}=0.96, \mathrm{PNFI}=0.85$ olarak hesaplanmıştır. Bu değerler ölçeğin iki faktörlü yapısının mevcut çalışma grubunda da doğrulandığını göstermektedir. Yirmi iki maddeden oluşan iki faktörlü yapının madde faktör yük değerleri 0.62 ile 0.88 arasında değerler alırken, maddelere ilişkin t değerleri ise 10.24 ile 17.18 arasında değişmektedir.

\section{Verilerin Analizi}

Araştırmadan elde edilen veriler SPSS 22 İstatistiksel Paket Programı ile analiz edilmiştir. Verilerin analizinde istatistikî yöntem olarak; frekans, aritmetik ortalama, standart sapma, t-testi, Tek Yönlü Varyans Analizi, basit doğrusal regresyon analizi ve Pearson Correlation testi kullanılmıştır. Verilerin parametrik testlerin ön şartlarını sağlayıp sağlamadığına Çarpıklık ve Basıklık değerleri ve Levene testi sonuçları incelenerek karar verilmiştir (Büyüköztürk, 2008). Ayrıca ölçme araçlarının geçerliğine ilişkin Doğrulayıc1 Faktör Analizi yapılmıştır. Bunun için Lisrel 8.7 Paket Programından faydalanılmıştır.

\section{Bulgular}

Bu bölümde katılımcılardan elde edilen "Öğretim Tekniklerini Seçebilme" ve "Öğretmen Öz-yeterlik Ölçeği” puan ortalamalarının bazı değişkenler açısından analizi sonucunda elde edilen bulgulara yer verilmiştir. Ölçme araçlarından elde edilen puanların dağılımı Tablo 1'de gösterilmiştir.

Tablo 1. Ölçme Araçlarmm Puan Dağılmmlar

\begin{tabular}{|c|c|c|c|c|c|c|c|c|}
\hline Boyutlar & $\begin{array}{l}\text { Madde } \\
\text { Say1s1 }\end{array}$ & $N$ & Ort & $S s$ & Çarp1klik & Basıklik & Min. & Max. \\
\hline $\begin{array}{l}\text { Teknik Seçimine İlişkin } \\
\text { Olumlu Öngörü }\end{array}$ & 15 & 227 & 4.03 & 0.89 & -0.93 & 1.10 & 1.00 & 5.00 \\
\hline $\begin{array}{l}\text { Teknik Seçimine İlişkin } \\
\text { Olumsuz Öngörü }\end{array}$ & 7 & 227 & 3.39 & 1.34 & -0.37 & -1.22 & 1.00 & 5.00 \\
\hline $\begin{array}{l}\text { Öğretim Teknikleri } \\
\text { Seçme(Toplam) }\end{array}$ & 22 & 227 & 3.71 & 0.83 & -0.22 & -0.57 & 1.00 & 5.00 \\
\hline Öğrenci Yükümlülüğg̈ & 8 & 227 & 6.85 & 1.08 & 0.99 & 0.94 & 3.75 & 9.00 \\
\hline Öğretim Stratejileri & 8 & 227 & 6.91 & 1.05 & -0.56 & 0.49 & 3.63 & 9.00 \\
\hline Sinıf Yönetimi & 8 & 227 & 7.00 & 1.09 & -0.51 & -0.13 & 3.38 & 9.00 \\
\hline $\begin{array}{l}\text { Öğretmen Öz-yeterlik } \\
\text { (Toplam) }\end{array}$ & 24 & 227 & 6.92 & 0.97 & -0.60 & 0.19 & 3.58 & 9.00 \\
\hline
\end{tabular}

Tablo 1'deki bulgulara göre, katılımcıların öğretim tekniklerini seçebilme ölçeği toplam puan ortalaması $3.71 \pm 0.83$ 'dür. Öğretim tekniklerini seçebilme öz-yeterlik inanc1 ölçeği alt boyutu puan ortalamas1 4.03 \pm 0.89 ile "Olumlu Öngörü” boyutunda iken, “Olumsuz Öngörü” boyutu puan ortalamas1 3.39 \pm 0.1.34'dür. Çalışmadaki bir diğer ölçme aracı olan öğretmen adaylarının öz-yeterlik inancı ölçeğinden aldıkları toplam puan ortalamasının $6.92 \pm 0.97$ olduğu görülmüştür. Bu ölçeğin alt boyutlarında en yüksek ortalama 7.00 \pm 1.09 ile "Sınıf Yönetimi” boyutunda iken, en düşük puan ortalamas1 $6.85 \pm 1.08$ ile "Öğrenci Yükümlülüğü" alt boyutundadır. Çalışmadaki her iki ölçme araçlarının çarpıklık ve basıklık değerleri dikkate alındığında dağılımın normal değerler arasında olduğu söylenebilir. 
Katılımcıların öğretmenlik öz-yeterlik inancı toplam puan ortalamaları ve öğretim tekniklerini seçebilmeye yönelik puan ortalamaları arasında anlamlı ilişki olup olmadığını belirlemek amacıyla yapılan Pearson korelasyon analizi sonucu elde edilen veriler Tablo 2'de verilmiştir.

Tablo 2. Öz-Yeterlik Toplam ve Alt Boyutlan İle Ögrgetim Teknikleri Ölçeği Toplam Puan Ortalamaları Arasindaki Iliskizye Yönelik Korelasyon Analizi

\begin{tabular}{lcccc}
\hline & $\begin{array}{c}\text { Öğrenci } \\
\text { Yükümlüğ̈̈ }\end{array}$ & $\begin{array}{c}\text { Öğretim } \\
\text { Stratejileri }\end{array}$ & Sinıf Yönetimi $^{\text {Toplam Ölçek }}$ \\
\hline Öğretim Tekniklerini Seçebilme r & .118 & $.225^{* *}$ & $.210^{* *}$ & $.210^{* *}$ \\
\hline
\end{tabular}
$\mathrm{p}<.001 * *$

Tablo 2 incelendiğinde, katılımcıların öğretim tekniklerini seçebilme ve öğretmenlik öz-yeterlik inanc1 puan ortalamaları arasında pozitif yönlü düşük düzeyde anlamlı ilişki bulunmuştur $(\mathrm{r}=.210 * *, \mathrm{p}<.001)$. Öğretmenlik öz-yeterlik inancı Ölçeği alt boyutlarından olan Öğrenci Yükümlülüğü (r=.118, p>.001) ile öğretim tekniklerini seçebilme yeterlik puan ortalaması arasında anlamlı ilişki saptanmamıştır. Öz-yeterlik inancı ölçeği alt boyutlanından öğretim Stratejileri $\left(r=.225^{* *}, \mathrm{p}<.001\right)$ ve sinıf yönetimi $\left(\mathrm{r}=.210^{* *}, \mathrm{p}<.001\right)$ ile öğretim tekniklerini seçebilme ölçeği puan ortalaması arasında pozitif yönlü düşük düzeyde anlamlı ilişki bulunmuştur. Bu bulgulardan katılımcıların öğretmenlik öz-yeterlik inancı puan ortalamasının olumlu olması öğretim tekniklerini seçebilme yeterliklerini olumlu etkilediği şeklinde bu durumu açıklamaktadır.

Öğretmenlik öz-yeterlik inancının öğretim tekniklerini seçebilme yeterliğini yordama gücünü belirlemek için yapılan basit doğrusal regresyon analizi sonucunda elde edilen veriler Tablo 3'de verilmiştir.

Tablo 3. Öz-Yeterlik Inancmm Öğretim Teknikleri Seçebilmeyi Yordamasına İlişkin Regresyon Analiz̧

\begin{tabular}{lccccccc}
\hline \multicolumn{1}{c}{ Değisken } & $\boldsymbol{B}$ & $\begin{array}{c}\text { Standart } \\
\text { Hata }\end{array}$ & $\boldsymbol{B}$ & $\boldsymbol{T}$ & $\boldsymbol{P}$ & $\boldsymbol{R}^{2}$ & $\boldsymbol{F}$ \\
\hline Sabit & 2.521 & 4.902 & 2.521 & 6.495 & .000 & .041 & 9.691 \\
Ö̈̆retim Teknikleri & .173 & .047 & .203 & 3.113 & .000 & & \\
\hline $\mathrm{R}=.203, \mathrm{R} 2=.041, \mathrm{~F}_{(1,226)}=9.691, \mathrm{p}<.01$ & & & & & \\
\hline
\end{tabular}

Tablo 3'deki bulgular dikkate alındı̆̆ında; öğretmenlik öz-yeterlik inancı ölçeğinin bağımsız değişken, öğretim tekniklerini seçebilme yeterlik algısının bağımlı değişken olarak kullanıldığ1 regresyon analizi sonuçlarına göre bağımlı değişkenin açıklanma düzeyi istatistiksel olarak anlamlıdır $[\mathrm{R}=.203, \mathrm{R} 2=.041, \mathrm{~F}(1$, $226)=9.691, \mathrm{p}<.01]$. Öğretim teknikleri seçebilme değişkenine ilişkin toplam varyansin \% 0.041 'ini öğretmenlik öz-yeterlik inancı bağımsız değişkeni ile açıklanmıştır. Ortaya çıkan $F_{(1,226)}=9.691$ değeri, katılımcıların öğretmenlik öz-yeterlik inancı öğretim tekniklerini seçebilme yeterlik algısını anlamlı düzeyde açıkladığını göstermektedir.

Araştırmaya katılan katılımcıların öğretmenlik öz-yeterlik inancı toplam ve alt boyutlarının, cinsiyet değişkenine göre farklılık gösterip göstermediğini incelemek amacıyla yapılan t-testi analizi sonucunda elde edilen veriler Tablo 4'te verilmiştir.

Tablo 4.Katılımcularn Cinsiyetine Göre Ögrretmenlik Öz-yeterlik İnancı Ölçeği ve Alt Boyut Puanlarna İlişkin T-Testi Analizi Sonuclar

\begin{tabular}{|c|c|c|c|c|c|c|}
\hline \multirow[t]{2}{*}{ Cinsiyet } & \multicolumn{2}{|c|}{$\operatorname{Kadin}(n=70)$} & \multicolumn{2}{|c|}{$\operatorname{Erkek}(n=157)$} & \multirow[b]{2}{*}{$t$} & \multirow[b]{2}{*}{$p$} \\
\hline & Ort. & Ss & Ort. & Ss & & \\
\hline Öğrenci Yükümlülüğ̈ü & 6.75 & 0.95 & 6.89 & 1.14 & -0.943 & 0.34 \\
\hline Öğretim Stratejileri & 6.80 & 0.99 & 6.96 & 1.07 & -1.019 & 0.30 \\
\hline Sınıf Yönetimi & 6.85 & 1.02 & 7.06 & 1.12 & -1.382 & 0.16 \\
\hline Ölçek (Toplam) & 6.80 & 0.94 & 6.97 & 0.99 & -1.210 & 0.22 \\
\hline
\end{tabular}

$\mathrm{p}>.05$

Tablo 4'te, katılımcıların öğretmen öz-yeterlik inancı ölçeğinden aldıkları toplam puan ortalamasının onların cinsiyetine göre farklılaşıp farklılaşmadı̆̆ını tespit etmek için yapılan t-testi analizi sonucu verilmiştir. Katılımcıların öğretmenlik öz-yeterlik inançları cinsiyete göre farklılaşmadığı tespit edilmiştir $(\mathrm{p}>.05)$. 
Araştırmaya katılan katılımcıların öğretim tekniklerini seçebilme algısı toplam ve alt boyutlarının, cinsiyet değişkenine göre farklılık gösterip göstermediğini incelemek amaciyla yapılan t-testi analizi sonucunda elde edilen veriler Tablo 5'te verilmiştir.

Tablo 5.Katıllmollarn Cinsiyetine Göre Öğretim Tekniklerini Seçebilme Yeterlik. Algisı Toplam ve Alt Boyut Puanlarna Iliskkin T-Testi Analizi Sonuclar

\begin{tabular}{lcccccc}
\hline Cinsiyet & \multicolumn{2}{c}{$\begin{array}{c}\text { Kadin } \\
(\boldsymbol{n}=\mathbf{7 0})\end{array}$} & \multicolumn{5}{c}{$\begin{array}{c}\text { Erkek } \\
(\boldsymbol{n}=\mathbf{1 5 7 )}\end{array}$} \\
\hline & Ort. & Ss & Ort. & Ss & t & p \\
\hline Teknik Seçimine İlişkin Olumlu Öngörü & 3.25 & 0.28 & 3.29 & 0.57 & -0.278 & 0.49 \\
Teknik Seçimine İlişkin Olumsuz Öngörü & 2.80 & 0.74 & 2.90 & 0.53. & -0.034 & 0.28 \\
\hline Ölçek (Toplam) & 3.17 & 0.45 & 3.22 & 0.56 & -1.976 & 0.55 \\
\hline p>.05 & & & & & &
\end{tabular}

Tablo 5'te, katıllımcıların öğretim tekniklerini seçebilme yeterlik alg1sı toplam puan ve alt boyutlarda cinsiyete göre farklılaşma göstermediği belirlenmiş̧tir ( $\mathrm{p}>.05)$. Katılımcıların öğretmen öz-yeterlik algılları toplam ve alt boyutlarının, akademik not ortalamaları ile nasıl bir ilişkiye sahip olduğunu tespit etmek amaciyla yapılan Pearson Korelasyon analizi sonucunda elde edilen veriler Tablo 6'da verilmiştir.

Tablo 6. Ögretmen Öz-yeterlik. Algısı İle Akademik Not Ortalaması Arasindaki İlişki

\begin{tabular}{lccc}
\hline & \multicolumn{3}{c}{ Akademik Not Ortalamas1 } \\
\hline Boyutlat & $\boldsymbol{N}$ & $\boldsymbol{R}$ & $\boldsymbol{P}$ \\
\hline Öğrenci Yükümlülüğ̈̈ & 227 & .061 & 0.36 \\
Öğretim Stratejileri & 227 & .156 & $\mathbf{0 . 0 1 *}$ \\
Sinıf Yönetimi & 227 & .114 & 0.08 \\
\hline Ölçek (Toplam) & 227 & .121 & 0.06 \\
\hline
\end{tabular}

Tablo 6'a göre; katılımcıların öğretmen öz-yeterlik ölçeğinden aldıkları puan ortalaması ile akademik not ortalaması arasında anlamlı ilişki tespit edilmemiştir ( $p>0.001)$. Katılımcıların akademik not ortalaması onların öğretmenlik öz-yeterlik algısı ile ilişkili değildir. Sadece katılımcıların öğretmen öz-yeterlik algısı ile ölçeğin alt boyutlarından olan "Öğretim Stratejileri”" arasında pozitif yönlü düşük düzeyde anlamlı ilişki mevcuttur ( $\mathrm{r}=.114, \mathrm{p}>.001)$. Akademik not ortalamas1 ile öğretim tekniklerini seçebilme yeterlik algis1 arasında ilişki olup olmadığını tespit etmek amacıyla yapılan analiz sonucu elde edilen bulgular Tablo 7'de gösterilmiştir.

Tablo 7.Öğretmenlik Tekniklerini Seçebilme Yeterlĭ̆i İle Akademik Not Ortalaması Arasinda Anlaml Bir İlişkiye Yönelik Korelasyon Testi Sonuclar

\begin{tabular}{lccc}
\hline & \multicolumn{3}{c}{ Akademik Not Ortalamasi } \\
\hline Boyutlar & $\boldsymbol{N}$ & $\boldsymbol{r}$ & $\boldsymbol{p}$ \\
\hline Teknik Seçimine İlisskin Olumlu Öngörü & 227 & .164 & $\mathbf{0 . 0 1 *}$ \\
Teknik Seçimine İlişkin Olumsuz Öngörü & 227 & .071 & 0.28 \\
\hline Ölçek (Toplam) & 227 & .145 & $\mathbf{0 . 0 2 *}$ \\
\hline
\end{tabular}

Katılımcıların öğretmenlik tekniklerini seçebilme yeterlik algıları ile akademik not ortalamaları arasındaki korelasyon katsayısı, akademik not ortalaması ile toplam ölçek ve alt boyutlarından "Olumlu Öngörü” arasında pozitif yönde ve düşük düzeyde anlamlı bir ilişki $(\mathrm{p}<0.05)$ olduğunu göstermektedir (Tablo 7). Diğer bir deyişle, akademik not ortalaması arttıkça katılımcıların öğretim tekniklerini seçebilme yeterlik algılarında artış meydana geldiği söylenebilir. Katılımcıların öğrenim gördükleri bölüme göre öğretmenlik öz-yeterlik ölçeğinden aldıklanı puan ortalamasının farklılık gösterip göstermediğini incelemek amacıyla yapılan tek yönlü varyans analizi sonucunda elde edilen veriler Tablo 8'de verilmişsir.

Tablo 8. Ögretmen Öz-yeterlik Algısı Katılimalarn Okuduklarn Bölüme Göre Farkllhk Gösterip Göstermediğini Tespiti İcin Tek Yönlü Varyans Analizi Sonuclar

\begin{tabular}{ccccc}
\hline Bölüm & $\begin{array}{c}\text { 1.Öğretmenlik } \\
(n=66)\end{array}$ & $\begin{array}{c}\text { 2. Antrenörlük } \\
(n=38)\end{array}$ & $\begin{array}{c}\text { 3. Yöneticilik } \\
(n=79)\end{array}$ & $\begin{array}{c}\text { 4.Rekreasyon } \\
(n=44)\end{array}$ \\
\hline
\end{tabular}


YILMAZ, ASLAN ve AYAN

Spor Bilimleri Fakültesi Öğrencilerinin Öğretmen Öz-yeterlik İnançları ve Öğretim Tekniklerini Seçebilme Yeterlikleri

\begin{tabular}{|c|c|c|c|c|c|c|c|c|c|c|c|}
\hline & Ort. & Ss & Ort. & Ss & Ort. & Ss & Ort. & Ss & $F$ & $p$ & $A F$ \\
\hline $\begin{array}{l}\text { Öğrenci } \\
\text { Yükümlülüğ̈u }\end{array}$ & 6.76 & 0.84 & 6.68 & 1.67 & 7.08 & 0.96 & 6.71 & 0.14 & 1.92 & 0.12 & - \\
\hline $\begin{array}{l}\text { Öğretim } \\
\text { Stratejileri }\end{array}$ & 6.91. & 1.11 & 6.66 & 1.07 & 7.13 & 0.93 & 6.73 & 0.14 & 2.31 & 0.76 & - \\
\hline Sınıf Yönetimi & 6.88 & 0.97 & 6.62 & 1.26 & 7.28 & 0.99 & 6.52 & 0.14 & 3.62 & 0.01 & $3-2$ \\
\hline Ölçek(Toplam) & 6.85 & 0.89 & 6.65 & 1.36 & 7.16 & 0.92 & 6.48 & 0.13 & 2.97 & 0.03 & $\begin{array}{l}3-2 \\
1-4\end{array}$ \\
\hline
\end{tabular}

Tablo 8'e göre, katılımcıların okudukları bölüme göre Öğretmen Öz-yeterlik Algıları Ölçeği puan ortalaması $\left(\mathrm{F}_{(3,226)}=2.97, \mathrm{p}<0.05\right)$ ile Sinıf Yönetimi $\left(\mathrm{F}_{(3,226)}=3.62, \mathrm{p}<0.01\right)$ alt boyutundan alınan puanların anlamlı bir şekilde farklılaştığını göstermektedir. Toplam ölçekten alınan puanlar incelendiğinde yöneticilik bölümünde okuyan öğrencilerin öğretmenlik öz-yeterlik alg1sı antrenörlük bölümünde okuyan öğrencilerden istatistiksel olarak yüksek olduğu görülmektedir. Ayrıca ölçeğin genelinde öğretmenlik bölümünde okuyan öğrencilerin öğretmenlik öz-yeterlik algis1 rekreasyon bölümünde okuyan öğrencilerden daha yüksek olduğu saptanmıştır. Katılımcıların öğrenim gördükleri bölüme göre öğretim tekniklerini seçebilme yeterlikleri ölçeğinden aldıkları puan ortalamasının farklılık gösterip göstermediğini incelemek amacıyla yapılan tek yönlü varyans analizi sonucunda elde edilen veriler Tablo 9'de verilmiştir.

Tablo 9.Öğretmen Öğretim Tekniklerini Seçebilme Algısı Katılımcılarn Okudukları Bölüme Göre Farkllık Gösterip Göstermediüini Tespit İcin Tek Yönlü Varyans Analizi Sonuçar

\begin{tabular}{|c|c|c|c|c|c|c|c|c|c|c|c|}
\hline \multirow[t]{2}{*}{ Bölüm } & \multicolumn{2}{|c|}{$\begin{array}{c}\text { 1. Ögretmenlik } \\
(n=66)\end{array}$} & \multicolumn{2}{|c|}{$\begin{array}{l}\text { 2. Antrenörlük } \\
(n=38)\end{array}$} & \multicolumn{2}{|c|}{$\begin{array}{l}\text { 3. Yöneticilik } \\
(n=79)\end{array}$} & \multicolumn{2}{|c|}{$\begin{array}{l}\text { 4.Rekreasyon } \\
\quad(n=44)\end{array}$} & \multirow[b]{2}{*}{$F$} & \multirow[b]{2}{*}{$p$} & \multirow[b]{2}{*}{$\overline{A F}$} \\
\hline & Ort. & $S_{s}$ & Ort. & $S_{s}$ & Ort. & $S_{s}$ & Ort. & $S_{s}$ & & & \\
\hline $\begin{array}{l}\text { Teknik Seçimine } \\
\text { İlisskin Olumlu } \\
\text { Öngörü }\end{array}$ & 4.09 & 0.85 & 3.61 & 0.89 & 4.05 & 0.68 & 4.13 & 0.65 & 3.85 & $0.01 *$ & $1-2$ \\
\hline $\begin{array}{l}\text { Teknik Seçimine } \\
\text { İliskin Olumsuz } \\
\text { Öngörü }\end{array}$ & 3.16 & 1.42 & 2.99 & 1.11 & 3.74 & 1.34 & 3.45 & 1.26 & 3.76 & $0.01 *$ & $3-2$ \\
\hline Ölçek(Toplam) & 4.03 & 0.89 & 3.30 & 0.68 & 3.90 & 0.94 & 3.79 & 0.69 & 4.82 & $0.00 *$ & $3-2$ \\
\hline
\end{tabular}

Tablo 9 dikkate alındığında; katılımcıların okudukları bölüme göre Öğretim Tekniklerini Seçebilme Ölçeği $\left(\mathrm{F}_{(3,226)}=4.82, \mathrm{p}<0.05\right)$ ile Olumlu Öngörü $\left(\mathrm{F}_{(3,226)}=3.85, \mathrm{p}<0.05\right)$ ve Olumsuz Öngörü $\left(\mathrm{F}_{(3,226)}=3.76\right.$, $\mathrm{p}<0.05)$ alt boyutlarından alınan puanların anlamlı bir şekilde farklılaştı̆̆ını göstermektedir. Toplam ölçekten alınan puanlar incelendiğinde yöneticilik bölümünde okuyan öğrencilerin ölçeğin genelinden elde ettikleri puan ortalaması; antrenörlük bölümünde okuyan öğrencilerin puan ortalamasından istatistiksel olarak yüksek olduğu görülmektedir. Ölçek puanları faktör bazında incelendiğinde Olumlu Öngörü alt boyutunda öğretmenlik bölümü öğrencileri antrenörlük bölümünde okuyan öğrencilerin puanlarından daha yüksek olduğu saptanmıştır. Olumsuz Öngörü alt boyutunda ise bölümü spor yöneticiliği olan öğrencilerin puan ortalaması antrenörlük bölümü öğrencilerinden daha yüksektir. Başka bir ifadeyle Olumlu Öngörü boyutu hariç; toplam ölçek ve Olumsuz Öngörü boyutunda bölümü spor yöneticiliği olan katılımcıların en yüksek puana sahip olduğu söylenebilir (Tablo 9).

Katılımcıların mezun oldukları lise türüne göre öğretmenlik öz-yeterlik ölçeğinden aldıkları puan ortalamasının farklılık gösterip göstermediğini incelemek amacıyla yapılan tek yönlü varyans analizi sonucunda elde edilen veriler Tablo 10 'da verilmiştir.

Tablo 10. Öğretmen Öz-yeterlik. Algısı Katılımcılarn Mezun Olduklar Lise Türüne Göre Farkllık Gösterip Göstermediğini Tespiti İ̧cin Tek. Yönlü Varyans Analiz̧i Sonuclar

\begin{tabular}{|c|c|c|c|c|c|c|c|c|c|}
\hline \multirow[t]{2}{*}{ Lise Türü } & \multicolumn{2}{|c|}{$\begin{array}{l}\text { 1.Anadolu Lisesi } \\
(n=121)\end{array}$} & \multicolumn{2}{|c|}{$\begin{array}{l}\text { 2. Spor Lisesi } \\
(n=58)\end{array}$} & \multicolumn{2}{|c|}{$\begin{array}{l}\text { 3. Meslek Lisesi } \\
(n=48)\end{array}$} & \multirow[b]{2}{*}{$F$} & \multirow[b]{2}{*}{$p$} & \multirow[b]{2}{*}{$\overline{A F}$} \\
\hline & Ort. & Ss & Ort. & Ss & Ort. & Ss & & & \\
\hline Öğrenci Yükümlülüğü & 6.85 & 1.00 & 6.82 & 0.96 & 6.88 & 1.41 & 0.40 & 0.96 & - \\
\hline Öğretim Stratejileri & 6.95 & 1.03 & 7.01 & 0.98 & 6.70 & 1.15 & 1.24 & 0.28 & - \\
\hline Sınıf Yönetimi & 7.01 & 1.07 & 7.12 & 1.07 & 6.80 & 1.18 & 1.38 & 0.31 & - \\
\hline Ölçek (Toplam) & 6.94 & 0.97 & 6.98 & 0.92 & 6.80 & 1.04 & 0.53 & 0.58 & - \\
\hline
\end{tabular}


ANOVA sonuçlar1, mezun oldukları lise türüne göre Öğretmen Öz-yeterlik Alg1sı Ölçeği $\left(\mathrm{F}_{(2,226)}=0.58, \mathrm{p}>0.05\right)$ ile Öğrenci Yükümlülüğ̈̈ $\left(\mathrm{F}_{(2,226)}=0.40, \mathrm{p}>0.05\right)$, Öğretim Stratejileri $\left(\mathrm{F}_{(2,226)}=0.28\right.$, $\mathrm{p}>0.05)$ ve Sosyal Destek $\left(\mathrm{F}_{(2,226)}=0.31, \mathrm{p}>0.05\right)$ alt boyutlarından alınan puanların anlamlı bir şekilde farklılaşmadığını göstermektedir. Bu bulguya göre, mezun olunan lise türüne göre ölçekten ve alt boyutlarından alınan puanların ortalamaları arasındaki fark, istatistiksel açıdan anlamlı değildir (Tablo 10). Katılımcıların mezun oldukları lise türüne göre öğretim tekniklerini seçebilme ölçeğinden aldıkları puan ortalamasının farklılık gösterip göstermediğini incelemek amacıyla yapılan tek yönlü varyans analizi sonucunda elde edilen veriler Tablo 11'de verilmiştir.

Tablo 11.Öğretim Tekniklerini Seģebilme Yeterlik Algısı Katılmollarn Mezun Oldukları Lise Türüne Göre Farklulk Gösterip Göstermediğini Tespiti İ̧in Tek Yönlü Varyans Analizi Sonuçlar

\begin{tabular}{|c|c|c|c|c|c|c|c|c|c|}
\hline \multirow[t]{2}{*}{ Lise Türü } & \multicolumn{2}{|c|}{$\begin{array}{l}\text { 1.Anadolu Lisesi } \\
(n=66)\end{array}$} & \multicolumn{2}{|c|}{$\begin{array}{l}\text { 2. Spor Lisesi } \\
(n=38)\end{array}$} & \multicolumn{2}{|c|}{$\begin{array}{l}\text { 3. Meslek Lisesi } \\
(n=79)\end{array}$} & \multirow[b]{2}{*}{$F$} & \multirow[b]{2}{*}{$p$} & \multirow[b]{2}{*}{$A F$} \\
\hline & Ort. & Ss & Ort. & Ss & Ort. & Ss & & & \\
\hline $\begin{array}{l}\text { Teknik Seçimine İlişkin Olumlu } \\
\text { Öngörü }\end{array}$ & 4.05 & 0.75 & 4.09 & 0.70 & 3.92 & 0.11 & 0.57 & 0.56 & - \\
\hline $\begin{array}{l}\text { Teknik Seçimine İlişkin Olumsuz } \\
\text { Öngörü }\end{array}$ & 3.46 & 1.37 & 3.26 & 1.36 & 3.37 & 0.18 & 0.43 & 0.65 & - \\
\hline Ölçek (Toplam) & 3.76 & 0.87 & 3.68 & 0.78 & 3.64 & 0.11 & 0.37 & 0.68 & - \\
\hline
\end{tabular}

ANOVA sonuçları, mezun oldukları lise türüne göre Öğretim Tekniklerini Seçebilme Yeterlik Algısı Ölçeği $\left(\mathrm{F}_{(2,226)}=0.68, \mathrm{p}>0.05\right)$ ile Olumlu Öngörü $((2,226)=0.56, \mathrm{p}>0.05)$ ve Olumsuz Öngörü $\left(\mathrm{F}_{(2,226)}=0.65\right.$, $\mathrm{p}>0.05)$ alt boyutlarından alınan puanların anlamlı bir şekilde farklılaşmadığını göstermektedir. Bu bulguya göre, mezun olunan lise türüne göre ölçekten ve alt boyutlarından alınan puanların ortalamaları arasındaki fark, istatistiksel açıdan anlamlı değildir (Tablo 11).

\section{Tartışma, Sonuç ve Öneriler}

Beden eğitimi öğretmen adaylarının mesleki öz-yeterlik inançları ve öğretim tekniklerini seçebilme yeterlik algılarının çeşitli değiş̧kenler açısından incelendiği çalışmada; öğretmen adaylarının "Öğretim tekniklerini seçebilme" ölçeğinden ortalama değerin üzerinde puana (3.71 \pm 0.83$)$ sahip oldukları tespit edilmiştir. Ayrıca "öğretmen öz-yeterlik" ölçeğinden de ortalama değerin üzerinde puana (6.92 \pm 0.97$)$ sahip oldukları belirlenmiştir. Bu durum beden eğitimi öğretmen adaylarının sahip oldukları mesleki yeterlik inançlarının öğretim yöntemlerini seçebilme yeterlik algılarına da olumlu derecede yansıdığ1 şeklinde yorumlanabilir. Ölçme araçları arasındaki ilişki düzeyini belirlemek amacıyla, "Öğretim tekniklerini seçebilme yeterlik algısı" ile mesleki yeterlik inancının toplam ve alt boyutları arasındaki ilişki korelasyon analiziyle belirlenmiştir. Sonuç olarak; öğretim tekniklerini seçebilme yeterlik alg1sı ile öğretmen yeterlik toplam puan ortalaması, öğretim stratejileri ve sınıf yönetimi boyutlanı arasında düşük düzeyde pozitif yönlü anlamlı ilişki saptanmışken $(\mathrm{p}<0.01)$; öğrenci yükümlülüğü boyutunda bir ilişki tespit edilmemiştir ( $>0.01)$. Mesleki yeterlik inancının alt boyutlanı olan öğretim stratejileri ve sınıf yönetiminin öğretim tekniklerini seçebilme algısı ile ilişkili olması, bu becerilerin kazandırılmasında beden eğitimi öğretmen adaylarının aktif olarak rol almasından kaynaklı olabileceği düşünülmektedir. Ayrıca öğretim teknikleri seçebilme değişkenine ilişkin toplam varyansın \% 0.041'ini öğretmenlik öz-yeterlik inancı bağımsız değişkeninin açıkladığı çalısmada belirlenmiştir.

Çalışmada beden eğitimi öğretmen adaylarının öğretmen öz-yeterlik algıs1 ile cinsiyet değişkeni arasında anlamlı ilişki saptanmamıştır ( $\mathrm{p}>0.05)$. Bu bulguyu destekler nitelikte çalışmalar literatürde yer almaktadır. Nakip ve Özcan'ın (2016) beden eğitimi öğretmen adayları üzerinde gerçekleştirdikleri çalışmada öğretmen öz-yeterliğinde cinsiyete göre anlamlı farklılığın olmadığ1 tespit edilmiştir. Atasoy ve Şahin'de (2017, s. 665) beden eğitimi öğretmen adayları ile yaptığı çalışmada öz-yeterliğin cinsiyete göre değişmediği bulgusunu elde etmiştir. Cinsiyete göre farklilık olmamasının nedeni; beden eğitimi öğretmen adaylarının almış oldukları eğitim-öğretim programının aynı olması, aynı ortamda, benzer yaşantılara sahip olmaları ile açıklanabilir. Ayrıca eğitimde sunulan firsat eşitliğinin kız çocuklarına sağladı̆̆ı özgüven duygusu ve kendine olan inancın mesleki hayata olumlu yansıması da bu sonuca neden olmuş olabilir. Yine

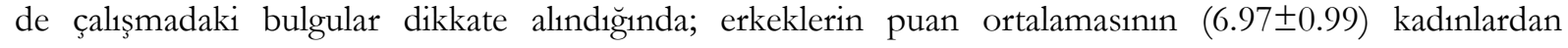


(6.80 \pm 0.94$)$ daha yüksek olduğu görülmektedir. Kafkas, Açak, Çoban ve Karademir’in (2010) beden eğitimi öğretmenlerinin öz-yeterliklerini incelediği çalışmada benzer bulguya ulaşılmıştır. Demirtaş, Cömert ve Özer 'de (2011, s.103) öğretmen adayları ile gerçekleştirdiği çalışmada erkeklerin öğretmen öz-yeterlik inancının kadınlardan daha yüksek olduğu bulgusuna ulaşmıştır. Literatürde cinsiyet ve öğretmen özyeterlik inancı konusunda yapılan çalışmalar dikkate alındığında; farklı sonuçları ortaya koyan çalışmaların olduğu görülmektedir. Bu farklılığın kaynağı öğretmen adaylarının inanç durumlarından kaynaklı olduğu söylenebilir.

Mevcut çalışmada beden eğitimi öğretmen adaylarının öğretim tekniklerini seçebilme yeterlik algisı ile cinsiyet değişkeni arasında anlamlı bir farklılık tespit edilmemiştir. Bu bulguyu destekler nitelikte çalışmalar literatürde yer almaktadır. Kayabaşı'nın (2012) öğretmenlerin öğretim sürecinde kullandıkları öğretim yöntem ve teknikleri konulu çalışmasında cinsiyet değişkeni ile öğretim yöntem ve tekniklerini tercih etme nedenleri arasında anlamlı farklılık bulunmamıştır. Çimen ve Yılmaz'ın (2013) öğretmen adaylarının öğretim yöntem ve teknikleri uygulamalarına ilişkin yeterlik algılarını inceledikleri çalışmada; cinsiyetin öğretmen adaylarının öğretim yöntem ve tekniklerini kullanma yeterlik algısının oluşmasında önemli bir etkisinin olmadığı saptanmıştır. Öğretmenlerin öz-yeterlik algıları ile öğretme-öğrenme anlayışları arasındaki ilişkinin incelendiği başka bir çalışmada, cinsiyet ve öğrenme-öğretme anlayışının öğretmenlerin öz-yeterlik algisı üzerinde etkisi olmadığını göstermiştir (Ocak, Ocak ve Kutlu-Kalendar, 2017, s. 1858).

Akademik olarak yüksek not ortalamasına sahip öğretmen adaylarının öğretmenlik bilgi ve becerisi açısından istenilen seviyeye sahip olduğu şeklinde bir algı kaçınılmaz olarak oluşmaktadır. Zimmerman ve Kitsantas'n (2005, s. 174) çalışmasında; öz-yeterlik ile akademik başarı arasında olumlu yönde ilişki olduğu tespit edilmiştir. Ancak öğretmen adaylarının öz-yeterlik inancı ve akademik not ortalaması arasında anlamlı ilişki olmadığına dair literatürde çalışmalar da yer almaktadır. Mevcut çalışmada da beden eğitimi öğretmen adaylarının öz-yeterlik inancı ile akademik not ortalaması arasında anlamlı ilişkinin olmadığı tespit edilmiştir.

Sadece ölçeğin alt boyutu olan öğretim stratejileri ile akademik not ortalaması arasında düşük düzeyde pozitif yönde anlamlı ilişki saptanmıştır. Ünlü, Kaşkaya ve Kızılkaya'nın (2017, s. 659) sosyal bilgiler öğretmen adaylarının öz-yeterlik inançlarını inceledikleri çalışmada, akademik not ortalaması mesleki özyeterlik algılarını etkilenmediği sonucuna ulaşmıştır. Nakip ve Özcan (2016, s. 789) beden eğitimi öğretmenlerinin öz-yeterlik inançlarını araştırdığı çalışmada, akademik not ortalaması ile öz-yeterlik arasında bir ilişki olmadığını bulmuştur. Akademik not ortalaması ve öğretmen adayların öğretim tekniklerini seçebilme yeterlik algisı arasındaki ilişkiyi tespit etmek amacıyla yapılan analiz sonucunda; ölçme aracının geneli ve teknik seçimine ilişkin olumlu öngörü boyutunda düşük düzeyde pozitif yönde anlamlı ilişki olduğu görülmüştür. Bu durum öğretmen adaylarının akademik not ortalamaları arttıkça, öğretim tekniklerini seçebilme yeterlik algılarının da arttığı şeklinde açıklanabilir.

Öğretim tekniği olarak öğretmenlerin kullanmış oldukları yaklaşımlar geleneksel ve çağdaş öğretim yaklaşımları olarak sınıflandırılmaktadır. Öğretim teknikleri açısından kendisini yeterli bulmayan öğretmen ya da öğretmen adayının öğretimi çeşitlendirebilecek teknikler yerine kendisinin aktif olduğu anlatım tekniklerini tercih ettikleri söylenebilir. Yapılan çalışmalar bu bilgiyi doğrular niteliktedir (Kayabaşı, 2012). Yılmaz ve Namlı'nın (2017, s. 3070) beden eğitimi öğretmen adayları ve uygulama öğretmenlerinin yeterliklerini inceledikleri çalışmada; uygulama öğretmenleri öğretmen adaylarının eğitim ve öğretimi çeşitlendiremediklerini belirttikleri görülmüştür. Aslantaş’a (2011, s. 499) göre bu durumun nedeni, öğretmenlerin hizmet içi eğitim sürecinde öğretim teknikleri, tekniklerin seçimi ve kullanımı konusunda yeterli bilgiyi alamamaktan kaynaklıdır. Kilmen, Kösterelioğlu ve Kösterelioğlu'nun (2007) farklı bölümlerde öğrenim gören öğretmen adaylarının ölçme ve değerlendirme araç ve yaklaşımlarına ilişkin yeterlik algılarını inceledikleri çalışmada; öğretmen adaylarının ölçme değerlendirme araç ve yaklaşımları konusunda kendilerini yetersiz ya da kısmen yeterli gördükleri belirlenmiştir. Benzer şekilde farklı branştaki öğretmen adayları üzerinde gerçekleştirilen bir diğer çalışmada ise; öğretmenlik uygulamasına katılan öğretmen adaylarının farklı yöntem ve teknikleri yeterince uygulayamadıkları, böylece bu konularda deneyim kazanamadıkları sonucuna ulaşılmışır. Aynı çalışmada öğretmen adayları anlatma ve soru sorma tekniğini yaygın olarak kullanabildikleri, diğer teknikler açısından kendilerini yetersiz hissettikleri tespit edilmiştir. Bu deneyimler, öğretmen adaylarının hizmet içi eğitimdeyken, pedagojik bilgi ve becerileri iyi kavrayarak, öğretmenlik uygulamasında uygulamaya koyarak elde edebilecekleri tecrübe ile kısmen de olsa kazanılabilecektir. Mevcut çalışmada, beden eğitimi öğretmen adaylarının öğretmen öz-yeterlikleri ve öğretim tekniklerini seçebilme algına ilişkin yapılan analiz sonucu; spor yöneticiliği öğrencilerinin sınıf yönetimi boyutu ve ölçeğin genelinde antrenörlük öğrencilerinden daha yüksek öz-yeterliğe sahip oldukları, 
aynı zamanda öğretim tekniklerini seçebilme yeterliklerinin de antrenörlük bölümü öğrencilerinden yüksek olduğu bulgusuna ulaşılmıştır. Beden eğitimi öğretmenliğ̣i öğrencilerinin öğretmen öz-yeterliklerinin ise rekreasyon öğrencilerinden yüksek olduğu, öğretim tekniklerini seçebilme yeterlik algısının da ölçeğin alt boyutu olan teknik seçimine ilişkin olumlu öngörü 'de antrenörlük öğrencilerinden yüksek olduğu tespit edilmiştir. Beden eğitimi öğretmenliği, antrenörlük ve rekreasyon bölümün daha yüksek YGS puanı ile öğrenci kabul etmektedir. Ayrıca spor yöneticiliği bölümü öğrencileri de YGS puanı ile tercih yapmaktadır. Dolayısıyla akademik başarıları diğer bölümlere göre yüksek olduğundan, öğrencilerin öğretmenlik bilgi ve becerilerine yönelik ilgi ve yeterlik algıları da yüksek olduğu düşünülmektedir.

Beden eğitimi öğretmen adaylarının mezun oldukları lise türü ile öğretmen mesleki yeterlik algıları ve öğretim tekniklerini seçebilme yeterlik algıları arasında anlamlı bir farkllık tespit edilmemiştir. Yaman, Cansüngü-Koray ve Altunçekiç (2005) yapmış oldukları çalışmada öğretmen adaylarının mezun oldukları lise türüne göre öğretmen öz-yeterlik algısı arasında anlamlı fark olmadığı sonucuna ulaşmıştır. Literatürde bu bulgunun aksini ortaya koyan çalşsmalar da bulunmaktadır. Kafkas, Açak, Çoban ve Karademir'in (2010) beden eğitimi öğretmen adayları üzerinde gerçekleştirdiği çalışmada, meslek lisesi mezunlarının kendilerini diğer lise mezunlarından daha yetersiz gördükleri tespit edilmiştir. Spor lisesi mezunu ögrencilerin ise kendilerini daha yeterli gördükleri tespit edilmiştir. Bu durum nedeni, spor lisesi mezunu öğretmen adaylarının bilgi ve becerilere daha fazla maruz kalmalarından kaynaklı olduğu düşünülmektedir.

Sonuç olarak beden eğitimi öğretmen adaylarının cinsiyetleri öz-yeterlik inançları ve öğretim tekniklerini kullanabilme yeterlik algılarının belirleyicisi olmadığı araştırmada saptanmıştır. Öğretim tekniklerini seçebilme yeterlik algılarının beden eğitimi öğretmen adaylarının öz-yeterlik inançları ile ilişkili olduğu sonucuna ulaşılmıştır. Öğretmen adaylarının öz-yeterlik inançları arttıkça öğretim tekniklerini kullanabilme yeterlik algısında da artış olduğu belirlenmiştir. Akademik başarının öz-yeterlik inancının ögretim stratejileri boyutu ile ilişkili olduğu saptanmıştır. Ayrıca akademik başarı öğretim tekniklerini seçebilme yeterlik algısı ile ilişkili olduğu görülmüştür. Bu sonuç öğretmen adaylarının öğretim stratejileri ve öğretim tekniklerini seçebilme gibi bilişsel kazanımların akademik başarı ile ilişkili olduğu anlamına gelmektedir. Beden eğitimi öğretmen adaylarının akademik başarıları öz-yeterlik algıları ve öğretim stratejileri düşük düzeyde de olsa ilişkili olması öz-yeterlik ve öğretim tekniklerini seçme yeterliği arasında bir ilişki olduğunu göstermektedir. Öğretmen adaylarının öğretmenlik öz-yeterlik inancı ile öğretim tekniklerini seçebilme yeterlik alg1sı ve mezun oldukları lise türü arasında anlamlı bir farklılık bulunmamıştır. Bu sonuç beden eğitimi öğretmen adaylarının lisans öğrenimi boyunca mesleğe ilişkin aldıkları eğitimin onların lisede aldıkları eğitimden kaynaklı farklılıkları ortadan kaldırmış olabileceği anlamına gelmektedir. Çalışmadan elde edilen bulgular dâhilinde, aşağıdaki önerilere yer verilebilir:

- Öğretmen adaylarına hizmet öncesi eğitimde elde ettikleri teorik bilgileri uygulamaya dönüştürülmesi için gerekli koşulların sağlanması gerekmektedir.

- Öğretmen adaylarının sahip oldukları öz-yeterlik inancının yüksek olması, öğretim tekniklerini seçebilme yeterlik algısını olumlu etkilediği sonucuna ulaşılmıştır. Bu nedenle hizmet öncesinde öğretmen adaylarının öz-yeterlik inançlarını yükseltecek uygulamalara firsat verilmelidir.

- Öğretmen adaylarının yeterliğine katkı sağlayabilecek bilgi ve becerinin hizmet öncesi eğitimde kazandırılması, onların gelecekte mesleklerinin yetki ve sorumluluklarını daha iyi uygulamaya koymalarına firsat sunacaktır.

- Spor liseleri müfredat açısından spor ve spora özgü ders içeriklerine daha fazla yer vermektedir. $\mathrm{Bu}$ durum spor lisesinde öğrenim gören öğrencilerin en azından konu alanı açısından diğer lise mezunlarından teorik ve uygulama bilgi ve beceri bakımından daha donanımlı olmasını gerektirmektedir. Ancak çalışmada lise türünün beden eğitimi öğretmen adaylarının öz-yeterlik ve öğretim tekniklerini seçebilme yeterlik algısı açısından bir farklılık göstermemiştir. Bu açıdan spor liselerinin işlevselliğini konu edinen bir çalsşma tasarlanarak, amacına hizmet etme durumu gözden geçirilebilir.

- Çalısma sadece nicel araştırma yaklaşımı ile tasarlanmıştır. Bir başka çalışmada, elde edilen sonuçların nedenlerinin daha ayrıntılı olarak incelenebilmesi için nicel bulguların nitel yaklaşımla desteklendiği bir karma araştırma kurgulanabilir.

\section{Kaynakça}


Arslantaş, H. İ. (2011). Öğretim elemanlarının öğretim stratejileri-yöntem ve teknikleri, iletişim ve ölçme değerlendirme yeterliklerine yönelik öğrenci görüşleri. Mustafa Kemal Üniversitesi Sosyal Bilimler Enstitüsü Dergisi, 8(15), 487-506.

Atasoy, M. ve Şahin, C. (2017). Beden eğitimi öğretmen adaylarının öğretmenlik mesleği özyeterlikleri ile öğrencileri tanıma yeterliğini kazanma düzeyleri. Pegem Atıf İndeksi, 661-670.

Ashton, P. (1984). Teacher efficacy: A motivational paradigm for effective teacher education. Journal of Teacher Education, 35(5), 28-32.

Bilen, K. (2014). Mikro öğretim tekniği ile öğretmen adaylarının öğretim davranışlarına ilişkin algılarının belirlenmesi. Erzincan Üniversitesi Ë̆itim Fakültesi Dergisi, 16(1), 181-203.

Bozpolat, E., Uğurlu, C. T., Usta, H. G. ve Şimşek, A. S. (2016). Öğrenci ve öğretim elemanlarının öğretim yöntem ve tekniklerine ilişkin görüşleri: Nitel bir araştırma. Dicle Üniversitesi Ziya Gökalp Eğitim Fakültesi Dergisi, 27, 8395.

Büyüköztürk, Ș. (2008). Sosyal bilimler için veri analiẓi el kitabı (9.Baskı). Ankara: Pegem Akademi.

Çapa, Y., Çakıroğlu, J. ve Sarıkaya, H. (2005). Öğretmenlik özyeterlik ölçeği Türkçe uyarlamasının geçerlik ve güvenirlik çalışması. Ë̆itim ve Bilim, 30(137), 74-81.

Çimen, O. ve Yılmaz, M. (2013). Biyoloji öğretmen adaylarının öğretim yöntem ve teknikleri uygulamalarına ilişkin yeterlik algilar1. Gazi Universitesi Egütim Fakültesi Dergisi, 33(1), 51-65.

Demirtaş, H., Cömert, M. ve Özer, N. (2011). Öğretmen adaylarının öz-yeterlik inançları ve öğretmenlik mesleğine ilişkin tutumları. Ë̆itim ve Bilim, 36(159), 96-111.

Demirel, M. (2009). Sınıf öğretmenlerinin ve okul yöneticilerinin karakter eğitimine ilişkin öz-yeterlik inançları. Hacettepe Üniversitesi Ë̈itim Fakültesi Dergisi, 37(37), 36-49.

Denzine, G. M., Cooney, J. B. ve McKenzie, R. (2005). Confirmatory factor analysis of the Teacher Efficacy Scale for prospective teachers. British Journal of Educational Psychology, 75(4), 689-708.

Erden, M. (2007). Eğitim bilimlerine giriş. Ankara: Arkadaş Yayıncılık.

Ertan, H. ve Çiçek, Ş. (2003). Türkiye'de ilköğretim beden eğitimi derslerinde öğrenci başarısının değerlendirilmesine ilişkin yaklaşımlar. Hacettepe Üniversitesi Ë̆itim Fakültesi Dergisi, 25, 76-83.

Fırat Durdukaya, S., Yardımcıel, E., Beseren, H. ve Özbek, S. (2017). Öğretmen adaylarının öğretim tekniklerini seçme yeterliklerine ilişkin alg1 ölçeği. Elektronike Sosyal Bilimler Dergisi,16(61), 397-411.

Gratton, C. ve Jones, I. (2004). Analyzing data II: Qualitative data analysis. Research Methods For Sport Studies, 217-227.

Guskey, T. R. ve Passaro, P. D. (1994). Teacher efficacy: A study of construct dimensions. American Educational Research Journal, 31(3), 627-643.

Kafkas, M. E., Açak, M., Çoban, B. ve Karademir, T. (2010). Beden eğitimi öğretmen adaylarının öz-yeterlik algıları ile mesleki kayg1ları arasındaki ilişki. İnönü Üniversitesi Ë̈itim Fakültesi Dergisi, 11 (2), 93-111.

Karasar, N. (2005). Bilimsel arastırma yöntemi. Ankara: Nobel Yayınevi.

Kayabaşı, Y. (2012). Öğretmenlerin öğretim sürecinde kullandıkları öğretim yöntem ve teknikleri ile bunları tercih etme nedenleri. Bahkesir Üniversitesi Sosyal Bilimler Enstitüsü Dergisi, 15(27), 45-65.

Kilmen, S., Kösterelioğlu, M. A. ve Kösterelioğlu, İ. (2007). Öğretmen adaylarının ölçme ve değerlendirme araç ve yaklaşımlarına ilişkin yeterlik alg1ları. Abant İzzet Baysal Üniversitesi Ë̆itim Fakültesi Dergisi, 7(1), 129-140

Kinzie, M. B., Delcourt, M. A. ve Powers, S. M. (1994). Computer technologies: Attitudes and self-efficacy across undergraduate disciplines. Research in Higher Education, 35(6), 745-768.

Klien, B. S., Matkins, J. J. ve Weaver, S. (1999). Initiation of a collaborative approach for elementary science methods courses: Teaching across collaborative highways (TEACH). Electronic Journal Of Science Education, 4(1).

Milner, H. R. ve Hoy, A. W. (2002, April). Knowledge of self in the development of teacher expertise. In Unpubl paper presented at the Annual Meeting of the American Educational Research Association, Session (Vol. 26, No. 3).

Mosston, M. ve Ashworth, S. (2008). Teaching physical education (1st online ed.). Retrieved January 3, 2009.

Nakip, C. ve Özcan, G. (2016). Öğretmen adaylarının öğretmenlik mesleğine yönelik öz-yeterlik inançları ile öğretmenlik mesleğine yönelik tutumları arasındaki ilişki. Mersin Üniversitesi Eğitim Fakültesi Dergisi, 12(3).

Ocak, G., Ocak, İ. ve Kutlu-Kalender, M. D. (2017). Öğretmenlerin öz-yeterlik alg1lar1 ile öğretme-öğrenme anlayışları arasındaki ilişkinin incelenmesi. Kastamonu Ë̆itim Dergisi, 25(5), 1851-1864.

Oddens, D. A. M (2004). Trend in ducth vocational education teacher training in terms of personal quality. In International Conference on VET Teacher Training. Vol.1: VET Teacher Training (pp.347-354). Ankara: SVET.

Önen, F., Mertoğlu, H., Saka, M. ve Gürdal, A. (2008). Hizmet içi eğitimin öğretmenlerin proje ve proje tabanlı öğrenmeye ilişkin bilgilerine ve proje yapma yeterliklerine etkisi: ÖPYEP örneği. Ahi Evren Üniversitesi Eğitim Fakültesi Dergisi, 11(1), 137-158.

Pajares, F. (1997). Current directions in self-efficacy research. Advances in Motivation and Achievement, 10(149), 1-49.

Pendergast, D., Garvis, S. ve Keogh, J. (2011). Pre-service student-teacher self-efficacy beliefs: An insight into the making of teachers. Australian Journal of Teacher Education, 36(12), 4.

Tamer, K. ve Pulur, A. (2001). Beden eğitimi ve sporda ögretim yöntemleri. Ankara: Kozan Ofset.

Tschannen-Moran, M. ve Hoy, A. W. (2001). Teacher efficacy: Capturing an elusive construct. Teaching and Teacher Education, 17(7), 783-805. 
Uzunboylu, H. ve Hürsen, Ç. (2011). Lifelong learning competence scale (LLLCS): The study of validity and reliability. Hacettepe Üniversitesi Eğitim Fakültesi Dergisi, 41(41).

Ünlü, İ., Kaşkaya, A. ve Kızıllkaya, M. F. (2017). Sosyal bilgiler öğretmen adaylarının öz-yeterlik inançlarının çeşitli değişkenler açısından incelenmesi. Kırşehir Ë̆itim Fakültesi Dergisi, 18(2).

Wheatley, K. F. (2005). The case for reconceptualizing teacher efficacy research. Teaching and Teacher Education, 21(7), 747-766.

Yaman, S., Cansüngü-Koray, Ö. ve Altunçekiç, A. (2004). Fen bilgisi öğretmen adaylarının özyeterlik inanç düzeylerinin incelenmesi üzerine bir araştırma. Türk Ĕ̈itim Bilimleri Dergisi, 2, 3, 355-364.

Yilmaz, A. ve Naml, S. (2017). The opinions of supervising teachers and teacher cadidates participated to teaching practice about professional competency. Journal of Human Sciences, 14(3), 3061-3077.

Zimmerman, B. J. ve Kitsantas, A. (2005). Homework practices and academic achievement: The mediating role of self-efficacy and perceived responsibility beliefs. Contemporary Educational Psychology, 30(4), 397-417.

\section{EXTENDED ABSTRACT}

The concept of self-efficacy is important in achieving success in almost every field, in using the authority and responsibility in the best way and it is important in making the best possible and professional competence. This concept describes the knowledge, skills and attitudes which must be possessed to have the teachers to fulfill required duties and responsibilities, if it is evaluated in terms of teacher. In relation with this knowledge and skills, the selection of the teaching methods according to the needs and characteristics of the students comes first. With reference to this point, the aim of the research is to determine the self-efficacy perceptions of physical education teacher candidates in order to choose the self-efficacy beliefs and teaching techniques.

The research was designed with the relational scanning model from the quantitative research approach. The research was carried out amount third and fourth year students in Kirlkkale University Faculty of Sports Sciences in 2017-2018 academic years, spring semester while the students continued their education. A total of 227 students, 66 of the Department of Physical Education and Sports Teaching, 38 of the Department of Coaching Education, 79 of the Department of Sports Management and 44 of the Department of Recreation were included in the study on the basis of voluntary participation. In this study, the data collected by the researchers was used to obtain general demographic information such as gender, grade point average, department of education, high school graduation type through Personal Information Form. 9 Likert type teaching self-efficacy measurement instrument consisting of 24 items adapted to Turkish by Çapa, Çakıroğlu and Sarıkaya (2005) was used. The measurement tool has sub-dimensions such as classroom management competence, teaching strategies competence and student responsibility competence. Cronbach's Alpha internal consistency coefficient calculated on the data collected within the scope of the study was 0.92 . To determine the competencies of selecting teaching methods, the teacher candidates to choose teaching techniques proficiency scale developed by Firat Durdurkaya et al. (2017) was applied. The measurement tool is in the type of 5 Likert and consists of 22 items and has two subdimensions: "positive foresight for technical selection" and "negative foresight for technical selection". Descriptive statistics (arithmetic mean, standard deviation), independent groups t-test, one-way variance analysis, simple linear regression analysis and Pearson correlation test were used. Data from the study were analyzed using SPSS 22 Statistical Package Program. Statistical methods were used for analysis of data: frequency, arithmetic mean, standard deviation, t-test, one-way variance analysis, simple linear regression analysis and Pearson Correlation test. It was decided whether the data met the preliminary conditions of parametric tests by examining the deviation and tightness values and Levene test results (Büyüköztürk, 2008). In addition, confirmatory factor analysis was performed regarding the validity of measurement instruments. Lisrel 8.8 Package Program has been used for this purpose. As a result, the total score average of teacher candidates was $6.92 \pm 0.97$.

At the lower dimensions of the scale, the highest average is $7.00 \pm 1.09$ for the 'Classroom Management' and the lowest average score is $6.85 \pm 1.08$ for the 'Student Obligation'. There was a meaningful correlation between the selection of the teaching techniques and self-efficacy belief scores with a low positive direction $(\mathrm{R}=.210, \mathrm{p}<.001)$. Teaching self-efficacy beliefs and the obligation of the student which is one of the sub-dimensions of the scale $(\mathrm{r}=.118, \mathrm{p}>.001)$ there was no significant correlation between the average of proficiency points and the ability to choose teaching techniques. It was 
determined that the total score average of the participants received from the teacher self-efficacy measure did not differ according to their gender ( $p>.05)$. There were no significant correlations between the average score and the academic grade average of the participants from the teacher self-efficacy scale $(p>0.001)$. There was a positive and low level correlation between the correlation coefficient between the student's ability to choose teaching techniques and the academic grade average $(\mathrm{P}<0.05)$. When the scores obtained from the total scale are examined, it is observed that the self-efficacy perception of the students for teachers studying in the management department is statistically higher than the students studying in the coaching department $(\mathrm{p}>0.05)$. In addition, it was determined in general for the scale that the selfefficacy perception for teachers in students in the teaching department were higher than the students in the recreation department $(\mathrm{p}>0.05)$. The difference between the mean scores obtained from the scale and subscales of the participants according to the type of high school they graduated from is not statistically significant $(\mathrm{p}>0.05)$. It was found that the teacher candidates had a score above average $(3.71 \pm 0.83)$ and a score above average $(6.92 \pm 0.97)$ from the "ability to choose teaching techniques" scale, and this could be interpreted as positively reflected in the ability to select the teaching methods according to the students in the perceptions of the teacher candidates. Among the findings obtained from the study, it is recommended that teacher candidates be provided with the necessary conditions to convert the theoretical knowledge they obtained in pre-service education into practice and that teacher candidates be given opportunities to practice to increase their self-efficacy beliefs. 